\title{
Research on Co-construction of Practical Teaching System of Fine Arts in Sino-Russia Universities
}

\author{
Zhongfeng $\mathrm{Fu}$ \\ College of Art and Design \\ Heihe University \\ Heihe, Heilongjiang, China 164300
}

\begin{abstract}
With the reform and opening-up, the education in China enters the age of globalization. The friendly relationship between China and Russia contributes to the upsurge of SinoRussian cooperation in running schools. The Co-construction of practical teaching system of fine arts in Sino-Russia universities also makes achievements and has important meaning for the international education cooperation of our country. However, problems still exist in this process and need improvement. (The conditions, achievements, problems and suggestions in Coconstruction of practical teaching system of fine arts in SinoRussia universities are discussed and researched in this paper.)
\end{abstract}

Keywords-Sino-Russia; universities; Co-construction; practical teaching of fine arts; innovation; teaching reform

\section{INTRODUCTION}

At present, our country is in the new period of reform and opening-up. The reform and opening-up has influenced education cause. Economic globalization drives the globalization of education cause. An increasing number of students studies abroad. Cooperation in running schools also springs up, especially between China and Russia. China borders upon Russia. The exchange between two countries has been increasingly frequent since the reform and opening-up. The friendly development of relationship between China and Russia promotes the development of education cooperation between two countries. Nineteen universities like Heihe University and Northeast Agricultural University of Heilongjiang Province of China cooperate with Russia in running schools. The construction of practical teaching system of fine arts by two countries has made great achievements.

\section{CONDITIONS FOR CO-CONSTRUCTION OF PRACTICAL TEACHING SYSTEM OF FINE ARTS IN SINO-RUSSIA UNIVERSITIES}

The Co-construction of practical teaching system of fine arts in Sino-Russia universities needs mature conditions. The cultural exchange of China and Russia and the construction of practical teaching base are necessary to Sino-Russian cooperation in running schools.

This paper is the phased research results of research backbone funding project of Heihe University and teaching reform project of higher education of Heihe University, project number: XJG1410.

\section{A. Cultural Exchange between China and Russia}

The relationship between China and Russia has become better and the exchange has increased since the reform and opening-up. Chinese Year and Russian Year were held in 2006 and 2007 respectively. But the young generation knows little about cultures in two countries. Therefore, teenagers of the two countries are encouraged to communicate and understand the culture of each other to strengthen cultural fusion. The cultural exchange and fusion in art field contribute to the Coconstruction of practical teaching system of fine arts.

\section{B. Construction of Practical Teaching Base}

First, the joint practical teaching base of fine arts of China and Russia provides place for the Co-construction of practical teaching system of fine arts by China and Russia. Heihe University of Heilongjiang began to construct the base from 2008 and received national special construction funds. Besides, the drawing specialty of fine art department of Heihe University establishes the provincial experimental plot with Sino-Russian cooperation to train applied undergraduates and art experimental teaching demonstration center. It greatly promotes the construction of Sino-Russian joint practice base of fine arts, which makes cooperation in running schools come true. Second, Russia has high quality teaching resources. The introduction of it can strengthen the construction of discipline of fine arts. The superior geographical position makes it easier for our country to bring in the profound teaching resources of fine arts and the high quality teacher resources. Students can feel Russian culture at short range so they have deeper and broader understanding of fine arts in practical teaching system.

\section{ACHIEVEMENTS IN CO-CONSTRUCTION OF PRACTICAL TEACHING S YSTEM OF FINE ARTS IN SINO-RUSSIA UNIVERSITIES}

Impressive achievements have been made since the Coconstruction of practical teaching system of fine arts in SinoRussia universities, including build characteristic joint teaching classroom, innovate in characteristic professional concept and reform teaching system.

\section{A. Build Characteristic Joint Teaching Classroom}

Distinguished teachers of China and Russia teach at the practical teaching base of fine arts. The introduction of high 
quality teaching resources of Russia provides platform for artistic communication and cooperation between Chinese universities and Russian universities. The practical teaching system of "one classroom of two countries" with characteristics of Sino-Russian cooperation in running schools forms. The development idea of "integration, practice and innovation" in teaching of fine arts is built and the importance of practical teaching in applied talent training is emphasized to cover the shortage of classroom theory and effectively improve students' skills of fine arts.

\section{B. Innovate in Characteristic Professional Concept}

In the Co-construction of practical teaching system of fine arts, implement Scientific Outlook on Development, establish the idea focusing on the development of students and teachers and. Establish the awareness of characteristic specialty to seek development. The characteristic professional concept influences the development direction of specialty construction. Therefore, the characteristic specialty construction should first reform the specialty construction and teaching idea and build new idea to meet the requirements of teaching reform. Meanwhile, teaching resources of art colleges of Russia like courses, teaching materials and teachers should be introduced to make the construction of practical teaching system of fine arts more characteristic.

\section{Reform Teaching System}

First, reform the teaching system, revise syllabus and teaching plan and properly bring in painting course of Russian universities and the way and awareness of creation in Russia. Specific scheme of teaching reform is researched through comparing Russian teaching methods and patterns of art with Chinese; second, teachers and students of China and Russia have different awareness and styles of creation. Mutual learning and communication between China and Russia promote the Co-construction of practical teaching system of fine arts; last, train applied talents, change single pattern of classroom teaching and strengthen experimental and practical teaching to train students' application and practical abilities, increase the proportion of practical teaching in the total credits.

\section{SignifiCANCE OF CO-CONSTRUCTION OF PRACTICAL TEACHING SYSTEM OF FINE ARTS IN SINO-RUSSIA} UNIVERSITIES

\section{A. Provide Experience for Sino-Russian Cooperation in Running Schools}

The Co-construction of practical teaching system of fine arts in Sino-Russia universities enriches the experience of Sino-Russian cooperation in running schools and practical teaching. The research results are promoted in many domestic provinces and provide platform for deeper education cooperation between China and Russia. It also provides experience for cooperation in running schools between China and other countries and improves the international education cooperation of China.

\section{B. Innovate in Teaching Pattern and Expand the Horizon of Students}

The introduction of high quality teaching resources of Russia makes for the reform of teaching pattern of our country. Teaching patterns more appropriate for growth of students are developed through comparison and integration of teaching patterns in China and Russia. The acceptance and understanding of different cultures in teaching help the innovation of inspiration of fine arts educators in our country. The different awareness and styles of fine arts creation in China and Russia expand the horizon of students in the two countries. They no longer rigidly adhere to the art style of their own countries but innovate and practice and create a new world of fine arts in differences.

\section{Make for the Communication between China and Russia in Other Fields}

The construction of practical teaching system of fine arts in Sino-Russia universities promote the communication between China and Russia in fine arts field and other fields. First, the Sino-Russian cooperation in running schools promotes cultural exchange. The learning of Chinese is popular in Russia. More and more Chinese people begin to learn Russian. Different customs contribute to the understanding and accelerate cultural fusion between China and Russia. Second, the Sino-Russian cooperation in running schools drives the economic development of them. Overseas students also promote the economic interaction and development. Last, more and more programs of Sino-Russian cooperation in running schools consolidate the political communication and provide good international development environment for our country.

\section{PROBLEMS IN CO-CONSTRUCTION OF PRACTICAL TEACHING S YSTEM OF FINE ARTS IN SINO-RUSSIA UNIVERSITIES}

Great achievements have been made in Co-construction of practical teaching system of fine arts in Sino-Russia universities. Problems still exist in Sino-Russian cooperation in running schools.

\section{A. Absence of System Guarantee}

In the Co-construction of practical teaching system of fine arts in Sino-Russia universities, contradictions are inevitable. The Sino-Russia cooperation in running system has a short history and lacks specific guarantee of laws and regulations. In this process, with the expansion of cooperation scope, the contradictions will enlarge because of the pursuit of interests of both sides. For example, no specific standards exist in charging overseas students. Their personal safety cannot be guaranteed. They are unfamiliar with the life abroad, medical treatment, traffic and culture.

\section{B. Difficulty in Communication}

The languages of China and Russia are different. Few students understand Russian. Although some students can speak English, difficulties exist in daily life and communication because of different English levels of them. In the cooperation in running schools, because of the different 
cultural customs, different understanding and style in the field of fine arts, contradictions are inevitable even the phenomenon of discrimination appears. It bothers the Co-construction of teaching system of fine arts.

\section{Centralized Area Distribution of Overseas Students}

The Sino-Russia universities send overseas students in Coconstruction of practical teaching system of fine arts. However, students gather in one area, live with compatriots and fail to integrate into life of foreign country. They still use national language so that the foreign language level cannot be improved. For example, most overseas students in Russia from Heilongjiang province gather in Far East area of Russia and still use Chinese. They fail to find proper jobs in Russia after graduation because of incompetent Russian. The foreign language that should be improved in foreign countries becomes the employment advantage of overseas students after they go back to China. But because of the absence of practice, their foreign language level is low. Therefore, the ability of overseas students is not improved and they face great employment pressure after going back to China.

\section{Inadequate Understanding of Fine Arts}

In the Co-construction of practical teaching system of fine arts, China and Russia will send teachers and students. Facing the style of fine arts of foreign countries, because of the absence of practice and life experience, students may fail to roundly understand course, principle and style of fine arts of another country in learning. Mandatory infusion education is more inadvisable. The superficial acceptance of fine arts education may cause confusion of knowledge and the phenomenon of "slavishly imitate others and lose own originality". More attentions should be paid to characteristics of fine arts and integration in teaching according to cultural and artistic differences of the two countries.

\section{SUGGESTIONS ON CO-CONSTRUCTION OF PRACTICAL TEACHING SySTEM OF FINE ARTS IN SINO-R USSIA UNIVERSITIES}

Measures should be taken timely to solve problems in Coconstruction of practical teaching system of fine arts in SinoRussia universities.

\section{A. Improve System Guarantee and Ensure Personal Safety}

In the Co-construction of teaching system, contradictions are inevitable because of different cultures and interests. China and Russia should improve laws and regulations applicable to education under the tendency of internationalization of higher education and standardize the cooperation in running schools to eliminate contradictions. Guarantee the personal safety of overseas students, establish and improve the system of medical care insurance for overseas students and system for paying tuitions. Sound management system is the key to successful cooperation in running schools.

\section{B. Strengthen the Adaptation Education for Students}

First, strengthen students' awareness of self-protection and understanding of customs, medical treatment, traffic, culture, self rescue and laws of Russia and protection of personal safety. Second, strengthen the knowledge education for students and improve their foreign language level and the learning of Chinese and Russian culture to make them competent in language communication and independent survival in foreign country. Improve students' ability and train useful talents through Co-construction of practical teaching system of fine arts. Last, strengthen the tolerance and respect of students for different cultures and make them observe the customs of the place.

\section{Establish the Pattern to Disperse Overseas Students}

In the Co-construction of practical teaching system of fine arts, overseas students should be dispersed to integrate into the life of foreign country and experience different cultures and life, contributing to the improvement of their foreign language level. In this process, students can experience differences and tolerance, improve ability in living and experience differences in fine arts of the two countries. Therefore, they will improve creative ability and style.

\section{Improve the Pattern of Teaching Cooperation and the Quality of Teachers}

In the Co-construction of practical teaching system of fine arts, Sino-Russia universities should improve the pattern of teaching cooperation and the quality of teachers. Training plan is formulated according to characteristics of students. They should give specific guidance for different understanding of cultural differences. Teachers shouldn't deny foreign culture blindly but absorb principle of fine arts in other country, integrate and innovate to train more excellent students.

\section{CONCLUSION}

The Co-construction of practical teaching system of fine arts in Sino-Russia universities depends on the friendly relationship between China and Russia. China and Russia provide support in fund, policies and educational resources for the Co-construction of teaching system of fine arts which has made remarkable achievements and promoted the development of fine arts in two countries. However, problems still exist in cooperation in running schools. We should take measures to improve it. The Co-construction of practical teaching system of fine arts by China and Russia plays a vital role in harmonious development of relationship between China and Russia and the political and economic communication between the two countries. The education cooperation between China and Russia will be improved further based on the Coconstruction of practical teaching system.

\section{REFERENCES}

[1] Guo Jianwei. Research on Major Problems in Sino-foreign Cooperative Education and Countermeasures [D], Northeast Normal University, 2011

[2] Song Liquan. Current Situation and Thinking on Sino-Russian Cooperation in Running Schools [J], China Higher Education Research, 2010(02)

[3] The Fourth Seminar of "History and Prospect of Sino-Russian Cooperation" [J], Journal of Heihe University, 2014(4) 
[4] Miao Hui. Discussion on Advantages and Prospects of Sino-Russian Cooperation in Running Schools [J], Journal of Qiqihar University (Philosophy and Social Science Edition), 2010(06). 